\title{
Crowe's Fraud Pentagon Analysis on the Development of Financial Statements in Banking in Indonesia
}

\author{
Annisa Meilida $^{1}$, Elia Mustikasari ${ }^{2}$ \\ Universitas Airlangga, Indonesia
}

\begin{abstract}
This study aims to identify and analyze the influence of financial targets, financial stability, external pressure, institutional ownership, and the quality of the external auditor on irregularities in the financial statements of Banks in Indonesia. This study uses a quantitative method, by taking a sample of 23 banks surveyed in the financial period 2011 to 2015. The analysis of research data is b using logistic regression analysis. The results of the research produce empirical evidence that the financial stability factor and external pressure significantly influence the financial statement irregularities. While financial targets, institutional ownership, and the quality of the external auditor did not significantly affect the financial statements irregularities
\end{abstract}

Keywords: financial statements irregularities, financial targets, financial stability, external pressure, institutional ownership, and the quality of the external auditor

\section{Introduction}

Frauds by companies to manipulate financial statements are often referred to as fraud, and the practice of fraudulent financial reporting is better known as Fraudulent Financial Reporting. Auditing and Assurance Fraudulent Financial Reporting is an intentional misstatement or omission of amounts or disclosures wuth the intent to deceive users. The definition of fraudulent financial reporting according to such statements is a deliberate misstatement, omission of any amount or disclosure with a view to deceiving users of financial statements (1).

The practice of fraudulent financial reporting is not a stranger to society. Many parties feel disadvantaged because they get information that is not appropriate. Losses may be more perceived by investors because the decisions they make are irrational and affect the failure to get a return on investment activity. Fraud will not only undermine the trust relationship between management and investors, but can also contaminate the values of the accounting itself.

Some of the fraudulent practices of financial reporting that undermined trust relationships between management and investors also occurred in Indonesia. As an example occurred in the manufacturing company PT Kimia Farma engaged in pharmaceuticals and has become a company go public. Based on indications by the Ministry of SOEs and Bapepam inspection, there was an overstatemet in the financial statements of PT Kimia FarmaTbk (KF) net profit for the year ended 31 December 2011. This misstatement occurred by overriding sales and inventories in three units and carried out by inflating the inventory price authorized by the production director to determine the value of inventory on PT KF's distribution unit as of December 31, 2011. In addition PT KF's management recorded double records of sales in two business units. From Kimia Farma case it can be seen that companies use ROA as a "tool" to manipulate financial statements. PT KF's stock price dropped dramatically when the error was revealed to the public (13).

The results of a survey conducted by the Association of Certified Fraud Examiner also proven from banking and finance companies in Indonesia, which until now is still susceptible to fraud cases.Fraud that occurred in the financial sector and banking in Indonesia is also not a new thing anymore. The elements in Crowe's fraud pentagon theory cannot simply be researched and thus require variable proxies. Proxies that can 
be used for this research include Pressure proxied with, financial targets, financial stability, external pressure, and institutional ownership.

Opportunity proxied by ineffective monitoring and the quality of external auditors; Rationalization proxied by change in auditor; Capability proxied by the change of company directors; and Arrogance which is proxied with frequent number of CEO's picture. These five factors are indicated to be the trigger for the increase of fraud, especially in recent years. The desire of the company to ensure the company's operational activities are continuous (going concern) with always looks good cause companies sometimes take a shortcut (illegal) that is by doing fraud.

\section{Literature and Hypothesis}

Fraud is not only narrowly defined as fraud, in the world of financial fraud can mean theft (article 362 of the Criminal Code), extortion and threats (article 368 of the Criminal Code), embezzlement (article 372 KUHP), cheating (article $378 \mathrm{KUHP}$ ), and so on.

Fraud is translated as cheating. In relation to financial reporting, the auditor is concerned to test whether an act of fraud leads to misstatement in financial reporting. Simply put fraud, intentional deception, lying, cheating, and stealing are words that are mutually synonymous although their understanding may vary depending on the context of the case. Deliberate fraud can be called fraud when an employee deliberately marks up the procurement of goods and services within a government agency for his or her personal interests. Lies can be called fraud when employees deliberately do not report accounting transactions that occur for the sake of profit.

There are two types of fraud, namely external and internal. External fraud is a fraud perpetrated by an outsider against an entity. For example, external fraud includes: fraud committed by a customer to a business, a taxpayer against the government, or a policy holder against an insurance company. And the type of internal fraud is an illegal act of employees, managers, and executives of the company. two types of misstatements relevant to the auditor's judgment about fraud in the audit of financial statements, namely misstatements arising as a result of fraud in financial reporting and fraud arising from undue treatment of assets, the following explanation (1):

1. Misstatements arising from fraud in financial reporting are misstatements or deliberate deletion of amounts or disclosures in financial statements to trick users of financial statements. Fraud in the financial statements may involve the following actions:

a. Manipulation, counterfeiting or alteration of accounting records or supporting documents that serve as a source of data for the presentation of financial statements.

b. Incorrect representation in or omission of financial statements of significant events, transactions or information.

c. Wrong misrepresentation of accounting principles relating to quantity, classification, presentation or disclosure.

2. Misstatements arising from undue treatment of assets (often referred to as misuse or embezzlement), relate to the theft of an entity's assets resulting in financial statements not presented in accordance with generally accepted accounting principles. Improper treatment of the entity's assets may be conducted in various ways, including embezzlement of goods or money receipts, theft of assets, or actions that cause the entity to pay the price of goods or services not accepted by the entity. The improper treatment of assets may be accompanied by false or misleading notes or documents and may involve one or more individuals between management, employees or third parties.

Competence described in pentagon fraud theory has a meaning similar to that capability previously described in the fraud diamond theory by Wolfe and Hermanson (2014). Competence/capability is the ability of employees to ignore internal controls, develop concealment strategies, and control the social situation for personal gain (5).

According to Crowe, arrogance is an attitude of superiority over the rights owned and feel that internal control or company policy does not apply to him. The theory that explores more in depth about the trigger factors of fraud is the pentagon fraud theory (Crowe's fraud pentagon theory). This theory was proposed by Crowe Howarth (2011) (5). The theory of pentagon fraud is an extension of the fraud triangle theory previously proposed by Cressey, in this theory adding two other elements of fraud namely competence and arrogance. 
According to Crowe Howarth (2011) cheating is a common and meaningful thing, which happens because of human ingenuity and is aimed at one side to gain more profit by misrepresentation. The Association of Certified Fraud Examiner or ACFE divides fraud into three main typologies or branches (5):

1. Asset loss (Asset missapropriation).

This action is in the form of theft, embezzlement, or misuse of assets owned by the company.

2. Wrong statement (Fraudulent missatement).

This typology states that the financial statements presented are not stated with the truth.

3. Corruption (Corruption)

This one fraud often occurs in the world of business and government. Corruption is an act of fraud that is difficult to detect and tends to be done by one person, but involves the other.

Fraud triangle is a theory proposed by Donald R. Cressey after doing research for his doctoral thesis in 1950. Sihombing in his research also mentions that fraud triangle is one of the basic concepts of fraud prevention and detection. Fraud triangle explains why someone cheats. This theory is also supported by Huntonwho said that fraud or fraud occurs as a result of the interaction between three factors, namely opportunity, incentives or pressure, and attitude or rationalization (18).

Statesthat pressure is a person's motivation to commit fraud, usually because of the financial burden. In addition, pressure (pressure) is caused due to conditions, circumstances, or demands of someone to commit fraud (19). According to SAS No. 99, there is a common condition that can cause a person to cheat:

1. Financial stability

2. External pressure

3. Personal financial needs

4. Financial targets

Wind (2014) explains that fraudulent financial statements are deliberate or negligent in reporting financial statements in which the financial statements presented are not in accordance with generally acceptable accounting principles. This omission or deliberate nature is material so that it can affect the decisions to be taken by the interested parties.

1. Influence of Financial Target with Financial Statement Irregularities

Financial targets in the form of profit on the business to be achieved by the company is often called the financial target. One measure to assess the level of profit earned by the company for the business issued is Return On Assets. The higher the company's ability to achieve its financial goals can be said that the company's performance the better. But sometimes there are certain factors that cannot be controlled by the company to make the financial target is not achieved and the existence of the company will be in doubt.

H1: There is a significant influence of financial target factors on the deviation of financial statements on banks in Indonesia.

2. The Influence of Financial Stability with Financial Statement Irregularities.

SAS No. 99 explains that when financial stability is threatened by the state of the economy, industry, and situation of the operating entity, managers face the pressure to conduct financial statement fraud. The company's financial stability is measured by the total increase of total assets from year to year. The low total assets owned will put pressure on the management because the performance of the company looks declining so that it may reduce the flow of investment funds in the next year (19).

The case where the company experiences industry growth is below average, management is likely to manipulate financial statements to improve the company's prospects (19).

Based on the description, the research hypothesis proposed are:

$\mathrm{H} 2$ : There is a significant effect of the financial stability factor on the distortion of financial statements in Indonesian banks.

3. Effect of External Pressure with Financial Statement Irregularities

External pressure is a situation where the company gets pressure from outside the company. To cope with these pressures, companies need additional debt or external financing sources to remain competitive, including research financing and development or capital expenditures (19).

External pressure is proxied by using the leverage ratio that is the ratio between total liabilities and total assets. 
Obeua also explains that greater leverage can be attributed to the greater likelihood of credit breaches and lower ability to obtain additional capital through loans (13).

H3: There is a significant influence of external pressure factors on the distortion of financial statements to banks in Indonesia.

4. Influence of institutional ownership with Financial Statement Irregularities

There is an indication that institutional ownership within a company will be a pressure for the company itself. This pressure occurs because the management has a greater responsibility due to the responsibility carried out not only to an individual, but to the institution. In addition, the large share ownership by the institution rather than the individual makes management to do more business so as not to lose the investors, one of them by beautifying the financial statements through manipulation action.

Based on this can be indicated, the greater the ownership of shares by the institution, the greater the likelihood of the company feeling pressured to commit fraudulent financial reporting.

H4: There is a significant effect of institutional ownership on the deviation of financial statements on banks in Indonesia.

\section{Effect of Auditor Quality with Financial Statement Irregularities}

The appointment of an external auditor by the firm's audit committee is considered capable of conducting independent checks so as to avoid conflicts of interest and to ensure the integrity of the audit process. Research on the quality of external auditors focuses on the difference between the audit service selection from the public accounting firm (KAP) by the company ie, BIG4.

And non BIG4. The underlying reason for this is that KAP BIG 4 is considered to have more ability to detect and reveal reporting errors in management. For some reason, if a company is audited by KAP BIG4, then the opportunity to detect fraud will be greater, because KAP BIG 4 is considered more capable of detecting fraud and producing higher quality audit results.

H5: There is a significant influence of the auditor's quality factor on the distortion of financial statements to banks in Indonesia.

\section{Research Method}

This research was conducted on banking in Indonesia, that is by taking samples of several banks as research samples. The determination of the bank to be investigated is based on several considerations, namely the availability of financial statements, completeness of research variable information, and other considerations to be determined at the next research stage. The type of research data is the annual financial statements of the bank. Sources of data used in the study are secondary data in the form of bank financial statements in 2011 until 2015.

The research variables presented are as follows:

1. Financial Statement Irregularities

The dependent variable in this research is using restatement as the proxy of financial reporting (19). Explained that financial statement restatement or restatement of financial statements can give signals or signs of fraudulent financial reporting.

2. Financial Target

Financial targets in the form of profit on the business to be achieved by the company is often called the financial target. One measure to assess the level of profit earned by the company for the business issued is Return On Assets.

3. Financial Stability

SAS No. 99 explains that when financial stability is threatened by the state of the economy, industry, and situation of the operating entity, managers face the pressure to conduct financial statement fraud. The company's financial stability is measured by the total increase of total assets from year to year (19).

4. External pressure

External pressure is a situation where the company gets pressure from outside the company. To cope with these pressures, companies need additional debt or external financing sources to remain competitive, including research financing and development or capital expenditures (19).

External pressure is proxied by using the leverage ratio that is the ratio between total liabilities and total assets. 
5. Institutional ownership

Ownership of shares by institutions rather than individuals, where the greater the ownership of shares by the institution, the greater the likelihood of the company feeling pressured to commit fraudulent financial reporting.

6. Quality of external auditors

Use of audit services, ie whether using KAP BIG 4 or not.Tests on the hypothesis in this study was conducted using logistic regression. Logistic regression is used to test whether financial target variables, financial stability, external pressure, institutional ownership, and auditor quality influence the deviation of bank financial statements.

\section{Result}

\begin{tabular}{clrrr}
\multicolumn{5}{c}{ TABLE I: Description of Research Data } \\
\hline \hline No & Factor & Maximum & Minimum & Average \\
\hline \hline 1. & Financial Target & 3,41 & $-0,73$ & 1,54 \\
2. & Financial Stability & 761,06 & $-99,87$ & 23,98 \\
3. & External pressure & 97,39 & 0,08 & 83,65 \\
4. & Institutional ownership & 46,52 & 12,77 & 28,30 \\
\hline \hline
\end{tabular}

Based on the table, it can be seen that the financial target factor with the highest ROA ratio is $3.41 \%$ that is at Bank BRI in 2013. While the lowest value is -0.73 that is in Bank of India Indonesia in 2015. The average value ROA ratio as indicator of financial target factor is $1.54 \%$.

Based on the table, it can be seen that the financial stability factor with the value of asset change for two years is 761,06\% which is at Bank Rakyat Indonesia Agro Niaga in 2011. While the lowest value is $-99,87 \%$ that is at Bank Mayapada year 2011. The average value of financial stabiliats ratio is $23.98 \%$. Based on the table, it can be seen that the highest external pressure factor is $97.39 \%$ that is at Bank Mega in 2015. While the lowest value is equal to $0,08 \%$ that is at MayapadaBank in 2011 and year 2012. The average value of stabiliats ratio finance amounted to $83.65 \%$.

Based on the table, it can be seen that the highest institutional ownership factor is $46.52 \%$, ie at Bank Capital in 2015. The lowest value is $12.77 \%$, ie at Bank Rakyat Indonesia Agro Niaga in 2015. The average value of stabiliats ratio finance amounted to $28.30 \%$.

Feasibility Test of Logistic Regression Model The Hosmer and Lemeshow Test results are illustrated in the following table:

\begin{tabular}{ccc}
\multicolumn{3}{c}{ TABLE II: Goodness Of Fit Logistic Regression } \\
\hline Chi-square & df & Sig. \\
\hline 12,162 & 8 & 0,144 \\
\hline
\end{tabular}

The value of significance is 0.839 . A regression model that is worthy to show a significance value in the HosmerandLemeshow Test is more than 5\%. the significance value indicated in the table, above 5\% or more than 0.05 so that the goodness of fit model is good and the regression model is acceptable.

The next stage in logistic regression analysis is Assessing the overall regression model (overallmodel fit). To Assess the overall regression model is to pay attention to the value -2 Log Likelihood (LL) block number $=0$ and block number $=1$. The value $-2 \log$ Likelihood block number $=0$ and block number $=1$ is presented in the following table.

\begin{tabular}{ccc}
\multicolumn{3}{c}{ TABLE IV: Overall Model Fit } \\
\hline \multicolumn{2}{c}{ Iteration History } & -2 Log Likelihood \\
\hline Step 0 & 1 & 137,943 \\
& 2 & 137,863 \\
Step 1 & 3 & 137,863 \\
\hline
\end{tabular}

If the value of Likelihood -2Log on block number $=1$ is smaller or decrease compared with block number $=$ 0 it can be concluded that the regression model as a whole is feasible. Referring to Table 4.10 the value $-2 \mathrm{Log}$ Likelihood on block number $=0$ is 137,943 while the value of $-2 \log$ Likelihood on block number $=1$ is 105,096 . Thus, the overall regression model is feasible because of a decrease in Likelihood -2Log value in block number 1. 
The Omnibus Test sof Model Coefficients in logistic regression analysis aims to determine whether all the independent variables or one of the independent variables affect the dependent variable. Omnibus Result Tests of Model Coefficients are shown by the following table:

\begin{tabular}{|c|c|c|c|c|}
\hline & & $\begin{array}{c}\text { Chi- } \\
\text { square }\end{array}$ & $\mathrm{df}$ & Sig \\
\hline \multirow[t]{3}{*}{ Step 1} & Step & 32,766 & 5 & 0,000 \\
\hline & Block & 32,766 & 5 & 0,000 \\
\hline & Model & 32,766 & 5 & 0,000 \\
\hline
\end{tabular}

The model significance value is 0.000. This indicates that based on the SPSS results the level of significance is below $5 \%$ or 0.05 indicating that the independent variables used together affect the deviation of financial statements or at least one of the variables used in the study affect the deviation of financial statements. The value of Cox and Snell R Square and Nagelkerke R Square, based on SPSS output results can be seen in the following table.

TABLE V: Cox \& Snell $R$ Square and Nagelkerke $R$ Square
\begin{tabular}{ll}
\hline Cox \& Snell $R$ Square & 0,248 \\
\hline Nagelkerke $R$ Square & 0,355 \\
\hline
\end{tabular}

Coxdan Snell $\mathrm{R}$ value is $\overline{0,248 \text { and NagelkerkeRSquare value is } 0,355}$ which means $35,5 \%$ variable of financial report deviation influenced by independent variable that is financial targets, financial stability, external pressure, institutional ownership, and quality of external auditor.

Assessing the Eligibility of the Regression Model.

The feasibility of the regression model can be determined from the value of Likelihood and goodness of fit. The niai -2Log Likelihood is contained in the following table:

\begin{tabular}{|cc}
\hline \multicolumn{2}{|c}{ TABLE VII:Model Fitting Information } \\
\hline Model & -2 Log Likelihood \\
\hline Intercept Only & 8,635 \\
Final & 8,627 \\
\hline
\end{tabular}

There was a Decrease value of -2 Log Likelihood of 0.008 or from 8.635 to 8.627. After knowing that the fit regression model, the next step is to test the parallel lines that aims to determine whether the selected logit function is correct. the desired value of significance is more than 0.05 or $5 \%$. The test of parallel lines is shown by the following table:

TABLE VIII: Test of Parallel Lines

\begin{tabular}{lccc}
\hline \multicolumn{1}{c}{ Model } & $\begin{array}{c}-2 \text { Log } \\
\text { Likelihood }\end{array}$ & $\begin{array}{c}\text { Chi- } \\
\text { Square }\end{array}$ & Sig. \\
\hline $\begin{array}{l}\text { Null } \\
\text { Hypothesis }\end{array}$ & 21,502 & & \\
General & 19,738 & 1,764 & 0,414 \\
\hline
\end{tabular}

TABLE IX: Variabel in The Equation

\begin{tabular}{|c|c|c|c|}
\hline No. & Factor & Sig. & Keterangan \\
\hline 1. & Financial Target & 0,519 & Not significant \\
\hline 2. & Financial Stability & 0,000 & Significant \\
\hline 3. & External Pressure & 0,043 & Significant \\
\hline 4. & Institutional Ownership & 0,212 & Not significant \\
\hline 5. & External Auditor Quality & 0,829 & Not significant \\
\hline & Constanta & 0,189 & \\
\hline
\end{tabular}

Based on the table, then the influence of each variable on the deviations of financial statements in banking companies in Indonesia can be explained as follows:

1. The Influence of Financial Targets against Financial Statement Irregularities

Based on the results of logistic regression test in Table 4:16 regression coefficient of financial target variable is 0.2003 with a significance value of 0.519 . The significant value is greater than $5 \%$ or 0.05 . This indicates that the financial target has no significant effect on the deviation of financial statements. Increased financial targets will have a direct impact on the application of financial report irregularities. An increase in financial target of 1 unit or $100 \%$ will increase the distortion of financial statements by $20 \%$. 
2. Influence Financial Stability against Financial Statement Irregularities

The regression coefficient of variable financial stability is 0.091 with a significance value of 0.000 . The significant value is less than $5 \%$ or 0.05 . This shows that financial stability has a significant effect on financial report irregularities. Increased financial stability, will not directly affect the application of financial report irregularities.

An increase in financial stability of 1 unit or $100 \%$ will increase the financial statements deviation by $9.1 \%$.

3. Influence of External Pressure against Financial Statement Irregularities

The regression coefficient of external pressure variable is -0.028 with significance value equal to 0,043 . The significant value is less than $5 \%$ or 0.05 . This indicates that external pressure has significant effect on financial report deviation. Increased financial stabilitywill have a direct impact on the application of financial report irregularities. An increase in external pressure of 1 unit or $100 \%$ will decrease the financial report deviation by $2.8 \%$.

4. The Influence of Institutional Ownership on Financial Statement Irregularities

The regression coefficient of institutional ownership variable is 0.070 with a significance value of 0.212 . The significant value is greater than $5 \%$ or 0.05 . This indicates that institutional ownership has no significant effect on financial report irregularities.

Improvement of institutional ownership will have no direct impact on the application of financial report irregularities. An increase in institutional ownership of 1 unit or $100 \%$ will be able to reduce the $7 \%$ financial report deviation.

5. Effect of External Auditor's Quality on Financial Statement Irregularities

The regression coefficient of external auditor quality variable is -0.113 with significance value equal to 0,829 . The significant value is greater than $5 \%$ or 0.05 . This shows that the quality of external auditors has no significant effect on financial report irregularities. Improvement to the quality of external auditors, will have no direct impact on the application of financial report irregularities. An increase in institutional ownership of 1 unit or $100 \%$ will be able to reduce the distortion of the financial statements by $13.3 \%$.

\section{References}

[1] Ajeng, Wind. 2014. Forensic Accounting. Jakarta: Dunia Cerdas.

[2] Arens, A.A., Elder, R.J., and Beasley, M.S., 2012. Auditing and Assurance Service - An Integrated Approach. 14 ${ }^{\text {th }}$ Edition.Pearson Education Limited, Edinburg UK. Belkoui. Ahmed. 2008. Teori Akuntansi. Jilid I. Edisi Keempat. Jakarta: Penerbit Erlangga.

[3] Budi santoso, Totok dan Nuritomo. 2014. Bank dan Lembaga Keuangan Lainnya. Edisi 3. Jakarta: Salemba Empat.

[4] Crowe Horwarth. 2011. The Mind Behind The Fraudsters Crime : Key Behavioral and Environmental Element.

[5] Chyntia Tessa. 2016. Fraudulent Financial Reporting :Pengujian Teori Fraud Pentagon pada Sektor Keuangan dan Perbankan di Indonesia. Semarang: Universitas Diponegoro.

[6] Damodar, Gujarati. 2011. Dasar-Dasar Ekonometrika. Jakarta: Erlangga.

[7] Ghozali, Imam. 2011. Aplikasi Analisis Multivariate dengan Program SPSS. Semarang: Badan Penerbit Universitas Diponegoro.

[8] Harahap, SofianSafri. 2012. Analisis Kritis Atas Laporan Keuangan. Jakarta: Rajawali Persada.

[9] Ikatan Akuntan Indonesia. 2015. Standar Akuntansi Keuangan. Edisi 1 Juli 2009. Salemba Empat: Jakarta.

[10] Kasmir. 2013. Manajemen Perbankan. EdisiRevisi. Jakarta: PT. Raja GrafindoPersada

[11] Lia Meliany. 2010. Pengaruh Keefektifan Pengendalian Internal dan Kesesuaian Kompensasi terhadap Kecenderungan Kecurangan Akuntansi. Jakarta: Universitas Pembangunan Nasional Veteran.

[12] Martantya,Daljono. 2013. Pendeteksian Kecurangan Laporan Keuangan Melalui Faktor Risiko Tekanan dan Peluang (Studi Kasus pada Perusahaan yang mendapat Sanksi dari Bapepam Periode 2002-2006). Diponegoro Journal Of Accounting. Vol.2, No.2, h 1-12.

[13] Munawir, S. 2010. Analisis Laporan Keuangan. Edisi Empat. Yogyakarta: Liberty.

[14] Salavei, Katsiaryna and Norman Moore. 2005. Signal Sent by Financial Statement Restatment. Journal of Financial Research. Vol 22, 2-3.

[15] Santoso, Singgih. 2009. Buku Latihan SPSS Statistik Parametrik. Jakarta: Elex Media Computindo.

[16] Sekaran, Uma. 2006. Metode Penelitian untuk Bisnis. Edisi 4. Buku 2. Jakarta: Salemba Empat.

[17] Sihombing, Kennedy Samuel. 2014. Analisis Fraud Diamond dalam Mendeteksi Financial Statement Fraud: Studi Empiris pada Perusahaan Manufaktur yang Terdaftar di Bursa Efek Indonesia (BEI) Tahun 2010-2012. Skripsi Program S1. Fakultas Ekonomika dan Bisnis Universitas Diponegoro. Semarang. 
[18] Skousen, C. J., K. R. Smith, dan C. J. Wright. 2009. Detecting and Predecting Financial Statement Fraud: The Effectiveness of The Fraud Triangle and SAS No. 99. Corporate Governance and Firm Performance Advances in Financial Economis, Vol. 13, h. 53-81

[19] Taswan. 2010. Manajemen Perbankan, Konsep, Teori, dan Aplikasi. Edisi 2. UPP AMP YKPN.

[20] Wolfe, David T and Dana R. Hermanson. 2014. The Fraud Diamond : Considering the Four Elements of Fraud. CPA Journal. $74.12: 38-42$. 